\title{
中塚隆介 学位論文審査要旨
}

$\begin{array}{ccccc}\text { 主查 } & \text { 林 } & & \text { 眞 } & \text { 一 } \\ \text { 副主査 } & \text { 汐 } & \text { 田 } & \text { 剛 } & \text { 史 } \\ \text { 同 } & \text { 佐 } & \text { 藤 } & \text { 建 } & \text { 三 }\end{array}$

\section{主論文}

Transient expression of bone morphogenic protein-2 in acute liver injury by carbon tetrachloride

（四塩化炭素による急性肝障害における骨形成因子-2の一過性発現）

(著者：中塚隆介、谷口真、平田みつひ、汐田剛史、佐藤建三)

平成19年 The Journal of Biochemistry 掲載予定 


\section{学 位 論 文 要 旨}

\section{Transient expression of bone morphogenic protein-2 in acute liver injury by carbon tetrachloride}

（四塩化炭素による急性肝障害における骨形成因子-2の一過性発現）

組織の損傷に伴い、再生過程を誘導する様々な要因が働く。その中でも損傷部位周囲か らの増殖因子などのサイトカインによる刺激は組織再生の重要な要素となっている。四塩 化炭素肝障害では主に未成熟の肝細胞が分化、増殖し肝細胞の再生を行っていると考えら れており、主に成熟肝細胞が増殖する部分肝切除とは異なる。このプロセスが発生初期の 肝形成と類似することから、四塩化炭素肝障害からの再生では発生初期と同様の刺激が関 与していると考えられた。

本研究では初期胚において心臓中胚葉や肝間充織から分泌され、原腸内胚葉の肝原基細 胞への分化を誘導するサイトカイン骨形成因子-2 (BMP-2) が四塩化炭素肝障害において一 過性に発現上昇することを見出し、BMP-2がova1細胞などの肝未分化細胞により分泌され肝 障害からの再生に関与している可能性を検討した。

\section{方 法}

四塩化炭素を投与したラットより摘出した肝臓のRNAを用いBMP-2及び肝再生などに関与 する遺伝子の発現をノーザン解析とRT-PCRにより解析した。また、四塩化炭素を投与した ラットの肝臓抽出物により BMP-2蛋白とBMP-2シグナルに関与する $\operatorname{Smad} 1$ のリン酸化をウエ スタン解析により調べた。組織におけるBMP-2の発現とoval細胞マーカーであるCK-19の発 現は免疫組織化学により 四塩化炭素を投与したラット肝臓切片を用いて抗BMP-2抗体、抗 CK-19により検出した。四塩化炭素投与肝臓におけるマクロファージ系細胞の関与を調べる ために、塩化ガドリニウムと四塩化炭素を投与したラット肝臓のRNAをマクロファージ及び モノサイトマーカーであるCD14のRT-PCRにより解析した。培養細胞におけるBMP-2の発現を 解析するにあたっては、oval細胞株、活性化肝星細胞株、肝癌細胞株、マクロファージ細 胞株から抽出したRNAを用い、BMP-2、CD14のRT-PCRによる解析を行った。

\section{結 果}

ラットへの四塩化炭素投与による肝障害と修復の過程はアルブミン発現低下と再上昇に 
より確認された。この肝障害モデルにおいてBMP-2発現が四塩化炭素の投与後 12 24時間に 上昇することがノーザン解析、RT-PCR及びウエスタン解析による解析により示された。ま た、BMP-2シグナルにより活性化するSmad 1 のリン酸化状態はウエスタン解析により確かめ られた。さらに四塩化炭素障害肝においていくつかの肝再生や発生初期の肝形成に関わる 因子の発現をRT-PCRにより解析したところ、BMP-2と同様に上昇していた。肝障害により浸 潤、活性化するマクロファージ系細胞がBMP-2の発現に関与しているかを調べるため塩化ガ ドリニウム処理後肝障害を誘導しBMP-2発現を解析したが、マクロファージの関与は観察さ れなかった。四塩化炭素障害肝の組織におけるBMP-2発現を免疫組織化学において解析した ところ、BMP-2の発現はやや小型の肝細胞に類似した細胞で見られた。また、oval細胞のマ ーカーであるCK-19の局在はBMP-2発現に類似した存在を示した。

\section{考 察}

慢性的な肝藏障害は肝臓の繊維化を引き起こすが、この過程の初期には肝細胞の損傷と 再生の過程が繰り返されると考えられている。本研究では、発生期の肝臓形成に関わる BMP-2が成体の肝臓においても四塩化炭素肝傷害により一過性に発現することを見出し、こ の活性が急性期の肝障害からの再生と肝臓の発生において関係している可能性を示唆した。

発生期に心臓中胚葉あるいは横中隔間葉より産生されたBMPのシグナルはGATA-4の発現 等を介して肝臓原基の形成、さらに肝臓形成期にはオートクラインなBMP-2のシグナルが HEXやアルブミンの発現に必須である。

oval細胞は骨髄単核球に由来する肝臓幹細胞様の細胞であるが、四塩化炭素肝傷害によ りBMP-2を産生する細胞である可能性が示唆された。以上のことから成熟肝での四塩化炭素 投与による肝障害では活性化したoval細胞あるいは前駆細胞が障害された肝細胞からのシ グナルを受けBMP-2の発現を促す可能性を提起した。

\section{結 論}

四塩化炭素肝障害における損傷治癒のプロセスおいてBMP-2がova1様細胞から分泌され、 障害肝の再生に関与している可能性が示唆された。 